\title{
Miten terveydenhuollon Suomessa pitäisi varautua ilmastonmuutoksen seurauksiin
}

\section{JOHDANTO}

Sosiaalilääketieteen yhdistyksen seminaarissa "Ilmastonmuutoksen terveysvaikutukset" (13.5.2019) pohdittiin myös muutokseen varautumista. Tämä kirjoitus perustuu seminaarissa pitämääni esitelmään.

Ilmastonmuutoksen vaikutus terveydenhuollossa ei rajoitu lämpenemiseen ja sen suoriin fyysisiin ja biologisiin vaikutuksiin. Ilmastonmuutos vaikuttaa myös yhteiskunnallisten muutosten kautta: terveystarpeet ja yhteiskunnan mahdollisuudet ja halukkuus vastata niihin voivat muuttua. Terveysjärjestelmän rakenne ja toiminnan sisältö voivat tulla uuden tilanteen eteen. Talous, elinkeinorakenne, kauppa, sosiaaliset olosuhteet muuttunevat ja niidenkin seurauksena ihmisten kulutustottumukset ja elämäntyyli ja mahdollisesti yhteisöjen hallinta. Ilmastopakolaisuus ja konfliktit voivat lisääntyä.

Tulevia muutoksia ja niiden aikataulua ja suuruutta on vaikea ennustaa. Suuruuteen vaikuttaa, kuinka hyvin luonnonvarojen riittävyys otetaan huomioon päätöksenteossa ja kuinka tehokkaasti hiilidioksidin ja muiden lämmittävien kaasujen määrää voidaan vähentää. Jos ehkäisytoimet tehdään hyvin, niiden sivuvaikutuksilla voi olla positiivisia vaikutuksia terveyteen, esimerkiksi ravinnon ja liikunnan kautta.

Ilmastonmuutoksella ja sen ehkäisyllä on useita ulottuvuuksia: vaikutukset terveyteen, terveydenhuolto ilmaston lämmittäjänä, terveysammattilaiset ehkäisyn toimijoina, varautuminen muutoksiin. Rikkaissa maissa terveydenhuolto on suuri elinkeino. On esitetty arvioita, että sen osuus ilmastoa lämmittävistä päästöistä on 4-8 \% (1). Maailman lääkäriliitto (WMA) on julkilausumissaan korostanut lääkäreiden vastuuta ilmaston muutoksen torjunnassa ja varautumi- sessa seuraamuksiin (2). WMA on perustellut vastuuta ilmastonmuutoksen torjunnan terveydellisillä yhteisvaikutuksilla ja varautumisen tuomalla mahdollisuudella laajemminkin puuttua terveyden sosiaalisiin määrittäjiin. Lääkäreiden merkitystä ilmastonmuutoksen torjunnassa voi verrata lääkäreiden ydinsodan vastaiseen liikkeeseen (IPPNW): tällä kansainvälisellä liikkeellä on ollut merkitystä ydinaseiden vähentämiseen.

\section{VARAUTUMINEN}

Varautumis-käsitteen rinnalla käytetään käsitettä sopeutuminen: "Ilmastonmuutokseen sopeutumisella tarkoitetaan toimia, joilla varaudutaan ja mukaudutaan ilmastonmuutokseen ja sen vaikutuksiin sekä toimia, joiden avulla voidaan hyötyä ilmastonmuutokseen liittyvistä vaikutuksista" (3). Mielestäni varautuminen on aktiivisempi termi:”... Varautumisen päämääränä on huolehtia onnettomuuksien ja häiriötilanteiden ehkäisystä, valmistautumisesta toimintaan niiden uhatessa tai sattuessa ja suunnitella toipuminen." (4). Keskeistä varautumisessa on vahvistaa yhteiskuntien resilienssiä (joustavuutta, mukautumiskykyä).

Ilmastonmuutoksen ehkäisy on selkeätä: kaikki toiminta, joka vähentää lämpenemistä ja luonnonvarojen vähenemistä, on tarpeellista. Varautumisessa punninta on monimutkaisempaa. Miten terveydenhuolto voisi varautua ilmastonmuutoksen seuraamuksiin, kun näiden seuraamusten suuruus ja laatu ovat vain todennäköisyyksiä? Milloin kannattaa varautua pienenkin mahdollisuuden muutokseen, milloin ei?

Ilmastonmuutoksen seuraamuksiin varautuminen koskee muuttuvia terveystarpeita ja mahdollisuutta vasta niihin. Lämpeneminen ja sään ääri-ilmiöt tuovat suoria vaikutuksia terveyden- 
huollon tarpeeseen. Suuremmat vaikutukset tarpeeseen syntynevät väestön liikkumisen, muuttuvan tautikirjon ja ilmastonmuutoksen eston seurauksena. Infektiotaudit lisääntynevät, mutta monet krooniset taudit vähentynevät elintapamuutosten ja ilmansaasteiden vähenemisen seurauksena. Mielenterveyden ongelmien kehitystä on vaikea ennustaa, koska se riippuu siitä, miten ilmastonmuutos etenee ja kuinka muutoksen ehkäisyä tehdään.

Terveydenhuollon infrastruktuuri on riippuvainen yhteiskunnan yleisistä varautumistoimista: ravintotuotanto ja vesihuolto, jätehuolto $(\mathrm{ml}$. jätevedet), liikkumisväylät ja kuljetusvälineet, sähkö ja muu energia, internet ja muu digitaalinen infrastruktuuri (5). Yleinen infrastruktuuri on riippuvainen talouden ja kaupan kehityksestä. Sitä on vaikea ennakoida, mutta suuretkin muutokset ovat mahdollisia. Omavaraisuuden tarpeesta keskusteltaneen jälleen. Talouden ja elinkeinoelämän muutokset vaikuttavat, missä ihmiset asuvat ja kuinka helppoa terveydenhuoltoon pääsy on. Se vaikuttaa sairaaloiden ja terveyskeskusten (tai vastaavien) sijoitukseen ja palveluiden keskittämiseen. Tämä pitäisi huomioida investoitaessa palveluihin.

Yksi erityiskysymys on teknologian ja tarvikkeiden (esim. lääkkeet, rokotteet, laitteet) saatavuus. Terveydenhuolto on erittäin riippuvainen erilaisista korkeateknologisista tuotteista. Tällä hetkellä näiden tuotteiden valmistus on keskittynyttä ja pääasiassa Suomen ulkopuolella tapahtuvaa.

Varautumisen tulisi näkyä myös ammattilaisten koulutuksen suunnittelussa. Etenkin lääkäreiden koulutus on pitkä ja ennakointi on tarpeen. Koulutettavien määrää ja koulutuksen sisältöä pohdittaessa ilmastonmuutoksen vaikutus tulisi olla yhtenä ulottuvuutena.

\section{SELVITYKSIÄ TERVEYDENHUOLLON VARAUTUMISESTA}

Vuoden 2018 kansainvälisessä ilmastoraportissa (6) esitetään viimeisin tieto ilmastonmuutoksen ennusteista ja ehkäisy- ja varautumistoiminnan tarpeellisuudesta. Erityisesti terveydestä ja terveydenhuollosta siinä on kuitenkin vain vähän. Maailman terveysjärjestön raportti (1) painottuu ilmaston lämpenemisen ja ilmansaasteiden yhteisvaikutuksiin. Se osoittaa, kuinka ilmaston lämpenemisen estotoimet toimivat myös terveystekoina, sekä suoraan että saasteiden vähenemisen myötä. Siinä esitetään suosituksia ja toimintatapoja, kuinka terveydenhuolto voisi muuttua ilmastojoustavaksi (climate-resilient health systems).

Tiedelehti Lancetin projekti seuraa 41 indikaattorin avulla, miten ilmastonmuutoksen terveysvaikutukset, vastuutus ja varautuminen maailmanlaajuisesti etenevät. Se julkaisi toisen seurantaraporttinsa vuonna 2018 (7). Tiedot on kerätty eri kansainvälisistä tietolähteistä ja indikaattorit on jouduttu rajaamaan sellaisiin, mistä tietoa on maailmanlaajuisesti saatavilla. Suomen tiedot ovat useimmissa indikaattoreissa mukana, mutta ei eriteltynä; muutamaa poikkeusta lukuun ottamatta raportissa ei ole maakohtaisia tietoja. Raportin johdannossa on perusteltu hyvin, miksi ilmastonmuutos on terveyskysymys ja minkälaisten yhteiskunnallisten ja biologisten vaikutusten kautta terveysvaikutukset syntyvät. Raportti listaa 69 kirjoittajaa 27 instituutista, mutta Suomesta ei ole ketään mukana.

Suomalaiset terveydenhuollon varautumista koskevat selvitykset ovat osa laajempaa kokonaisuutta tai yksittäisten asiantuntijoiden mietintöjä. Yhteenvetoni niistä on, että terveydenhuollon varautumista on mietitty lähinnä lämpenemisen suoranaisten vaikutusten vuoksi. Epäsuorista vaikutuksista (heijastevaikutuksista) on hajamietintöjä vesihuollon ja rakennusten kosteusvaurioiden suhteen. Heijastevaikutuksista palvelujärjestelmään en löytänyt mitään. Yleensäkin Suomen varautumissuunnitelmissa heijastevaikutusten tärkeys mainitaan, mutta niiden käsittely on ollut vähäistä.

Ensimmäinen kansallinen ilmastonmuutokseen sopeutumisen suunnitelma tehtiin vuonna 2005 YK:n ilmastosopimuksen jälkeen. Se oli osa valtioneuvoston eduskunnalle antamaa selontekoa energia- ja ilmastopolitiikan linjauksista. Vuoden 2014 suunnitelman (8) mukaan "... sopeutumissuunnitelman tavoitteena on varmistaa, että Suomi valmistautuu ajoissa ja riittävän hyvin ilmaston lämpenemiseen liittyviin sää- ja ilmastoriskeihin ja muihin ilmastonmuutoksen vaikutuksiin sekä kehittää uusia toimintatapoja ja työkaluja muutoksessa toimimiseksi”. Terveydestä on yksi kappale, joka keskittyy lämpötilaan, vesiepidemioihin, eläinperäisiin tauteihin ja mielenterveysongelmiin; terveydenhuollosta ei ole mitään. Heijastevaikutuksia ei myöskään 
käsitellä, vaikka todetaan: "Koska ulkomaankauppa tuottaa suuren osan Suomen bruttokansantuotteesta, maailmantalouden heilahtelut ja ilmastonmuutoksen vaikutukset muissa maissa ovat ratkaisevia Suomen taloudelliselle kehitykselle."

Ilmastolaissa (3) määritellään Suomen ilmastopolitiikan pitkän aikavälin suuntaviivat sekä säädetään ilmastopolitiikan suunnittelujärjestelmästä. Suomen ilmastopaneeli on ilmastolain määräämä tieteellinen elin. Siinä on ollut jäsenenä myös terveyden edustaja; terveydenhuoltoa tai sen varautumista paneelissa ei ilmeisesti ole käsitelty.

Valtioneuvoston tulevaisuuskatsauksen taustatyönä tehdyssä SIETO hankkeessa (5) käsitellään myös, miten ilmaston lämpeneminen vaikuttaa terveyteen. Ilmastoriskeinä käsitellään hellettä, vesiepidemioita, vektorivälitteisiä infektiosairauksia, liukastumistapahtumia ja sisäilmaongelmia. Terveydenhuollon varautumista ei ole käsitelty.

Kansalliseen riskiarvioon ilmasto oli otettu mukaan ensimmäisen kerran vuonna 2018 (4). Riskiarvion teko perustuu EU-lainsäädäntöön ja painopisteenä siinä ovat äkilliset vakavat tapahtumat. Turvallisuusuhat on luokiteltu: ilmastonmuutos, väestönkehitys, kaupungistuminen, muuttoliikkeet, köyhyys, nuorisotyöttömyys, ruokaturva, luonnonvarojen niukkuus, konfliktien luonteen muutos, epidemiat ja pandemiat. Terveys-kappaleen alla käsitellään mikrobilääkeresistenssiä, influenssapandemia (tai vastaava), vakavia eläintauteja ja kasvitautiepidemioita. Terveydenhuoltoa ei käsitellä, mutta montaa terveyteen ja terveydenhuoltoon vaikuttavaa tekijää käsitellään, esimerkiksi digitalisaation tuomaa haavoittuvuutta.

Maa- ja metsätalousministeriö koordinoi ryhmää, joka seuraa ja kehittää Kansallista ilmastonmuutoksen sopeutumissuunnitelmaa (8). Seurantaryhmä julkaisi väliarvioinnin suunnittelun etenemisestä keväällä 2019 (9). Arvion mukaan sosiaali- ja terveysministeriön toimialat ovat muista aloista jäljessä, myös suorien vaikutusten ennakoinnin suhteen. Heijastevaikutuksethan ovat useimmilla toimialoilla huonosti käsitelty.

Valtioneuvoston heijastevaikutuksia käsittelevä raportti (10) kuvaa eri reittejä ja tapoja, miten heijastevaikutukset voivat syntyä. Terveyden ja terveydenhuollon osalta raportti on kevyt ja esimerkit keskittyvät lähinnä tautiriskeihin.

\section{JOHTOPÄÄTÖKSET}

Ilmastonmuutos on keskeinen, WHO:n sanoin tämän hetken keskeisin, terveyskysymys $(1,7)$. Ilmastonmuutos terveys- ja terveydenhuoltokysymyksenä ei ole Suomessa ollut kunnolla esillä, mutta viime aikoina tietoisuus on lisääntynyt. Siitä ovat osoituksena lisääntynyt tutkimuskiinnostus, Suomen Akatemian ilmasto-ohjelma (11), seminaarit ja tämä Sosiaalilääketieteen Aikakauslehden numerokin. Varautumisessa on paikallista kiinnostusta, esimerkiksi Helsingin seudun ympäristöpalveluissa (12).

Miten terveydenhuollon Suomessa pitäisi varautua ilmastonmuutoksen seurauksiin? Aloituksena voisi olla Sosiaali- ja terveysministeriön (STM) koordinoima terveysalan toimintasuunnitelma; sosiaalialalle tulisi tehdä myös omansa. Kansallisen sopeutumissuunnitelmanhan mukaan kullakin alueella tulisi sellainen laatia, ottaen huomioon ilmastonmuutoksen kansainväliset heijastevaikutukset (9). Eri alojen asiantuntijoista ja käytännön terveydenhuollon toimijoista koostuva työryhmä voisi suunnitelman laatia. Tehtävänä olisi ennakoida, mitä vaikutuksia terveydenhuoltoon mahdollisilla yhteiskunnallisilla ja ympäristön muutoksilla voisi lähitulevaisuudessa olla. Kansainväliset skenaariot ja selvitykset toiminevat malleina.

Kuinka ryhmän ehdotukset tuodaan käytäntöön, riippuu ehdotusten sisällöstä. Luultavimmin toiminta jakaantuu palvelujärjestelmän ja keskushallinnon välille. Keskushallinnossahan on jo nyt monia toimijoita, joiden tehtäviin varautuminen yleisesti kuuluu, esimerkiksi terveysturvallisuuden ohjausryhmä, poikkeusolojen neuvottelukunta ja huoltovarmuuskeskus.

Suunnitelman taustaksi tarvitaan skenaariot odotettavissa olevista fyysisen ja sosiaalisen ympäristön muutoksista Suomessa. Skenaariot tulisi tehdä eri oletuksilla heijastevaikutuksista ja ilmastonmuutoksen torjunnan tavoista ja onnistumisesta. Heijastevaikutuksista erityisesti kaupan ja talouden muutokset Suomen ulkopuolella ovat tärkeitä. Kerätyn tiedon avulla pääteltäisiin, millaisia vaikutuksia terveyteen ja terveydenhuoltoon on oletettavissa. Sen jälkeen tehtäisiin olemassa olevan tiedon kokoaminen ja päättely 
vaikutuksista ihmisten terveyteen, ammattilaisten koulutukseen, palveluiden järjestämiseen, toimipisteisiin ja teknologiaan, taloudellisiin resursseihin ja tietotarpeeseen (tutkimukseen, tilastointiin, seurantaan). Työryhmän työtä kannattaa koordinoida muiden alojen sopeutumissuunnitelmiin.

\section{LÄHTEET}

1. World health Organization. COP24 special report: health and climate change 2018 . https://apps.who.int/iris/handle/10665/276405

2. World Medical Association: WMA declaration of Delhi on health and climate change 2017. https:/www.wma.net/publications/backgrounddocuments/

3. Ilmastolaki 609/2015. http://www.finlex.fi/fi/laki/alkup/2015/20150609

4. Sisäministeriö. Kansallinen riskiarvio 2018. Sisäministeriön julkaisuja 2019:5 Helsinki 2019. https://intermin.fi/julkaisut/ julkaisu?pubid=URN:ISBN:978-952-324-245-6

5. Tuomenvirta H, Haavisto R, Hilden M, ym. Sää ja ilmastoriskit Suomessa - kansallinen arvio 9/2018. Valtioneuvoston selvitys- ja tutkimustoiminnan julkaisusarja 43/2018, Helsinki 2018. https:/valtioneuvosto.fi/julkaisut/ julkaisu?pubid=URN:ISBN:978-952-287-601-0

6. Intergovernmental Panel on Climate Change (IPCC). Special Report on Global Warming of $1.5^{\circ} \mathrm{C}$, October 2018. https://www.ipcc. ch/2018/10/08/summary-for-policymakers-ofipcc-special-report-on-global-warming-of-1-5capproved-by-governments/
7. Watts N, Amann M, Arnell N et al. The 2018 report of the Lancet countdown on health and climate change: shaping the health of nations for centuries to come. Lancet 2018;392: 2479-2514. doi: https://dx.doi.org/10.1016/S0140-6736(18)32594-7

8. Maa- ja metsätalousministeriö. Kansallinen ilmastonmuutokseen sopeutumissuunnitelma 2022, Valtioneuvoston periaatepäätös 20.11.2014, Helsinki 2014. Luettu x.x.2019. https://mmm.fi/luonto-ja-ilmasto/ ilmastonmuutokseen-sopeutuminen

9. Mäkinen K, Sorvali J, Lipsanen A, Hilden M. Kansallisen ilmastonmuutokseen sopeutumissuunnitelman 2022 toimeenpanon väliarviointi. Maa- ja metsätalousministeriön julkaisuja 2019:11. Maa- ja metsätalousministeriö, Helsinki 2019. http:urn.FI/ URN:ISBN:978-952-366-000-7 http://julkaisut. valtioneuvosto.fi/handle/10024/161498.

10. Hilden M, Groundstroem F, Carter TR, Halonen M, Perrels A, Gregow H. Ilmastonmuutoksen heijastevaikutukset Suomeen. Valtioneuvoston selvitys- ja tutkimustoiminnan julkaisusarja 46/2016. Helsinki 2016. Luettu x.x.2019. https://tietokayttoon.fi/julkaisu?pubid=15405

11. Suomen Akatemia. Ilmastonmuutos ja terveys Akatemiaohjelma 2020 - 2023, Ohjelmamuistio 2019. Luettu x.x.2019. http://www.aka.fi/ globalassets/32akatemiaohjelmat/ilmastonmuutosja-terveys/clihe_ohjelmamuistio_fi.pdf

12. HSY Helsingin seudun ympäristöpalvelut. Ilmastonmuutos - hillintä ja sopeutuminen 2019. Luettu x.x.2019. https://www.hsy.fi/fi/ asiantuntijalle/ilmastonmuutos/Sivut/default.aspx

Elina Hemminki

LKT, tutkimusprofessori emerita

THL, Terveyden ja hyvinvoinnin laitos, Sosiaali- ja terveydenhuollon tutkimus 